\title{
Factors Affecting the Investment Climate, SMEs Productivity and Entrepreneurship in Nigeria
}

\author{
Paul Agu Igwe ${ }^{1}$, Amarachi Ngozi Amaugo ${ }^{2}$, Oyedele M. Ogundana ${ }^{3}$, Odafe
} Martin Egere, Juliana Amarachi Anigbo ${ }^{2}$

\begin{abstract}
In Nigeria, most of businesses operate in the form of Small and Medium Enterprises (SMEs). SMEs play a significant role in the economic development of many nations. This paper employs current perspectives to examine the factors affecting investment, productivity and growth of SMEs by employing the World Bank Enterprise Survey in Nigeria. It explored five main factors affecting investment and productivity in Nigeria as follows: education of the labour force, access to infrastructure, access to finance, size of firms and other business climate variables. Other business climate variables are insecurity, bribe or corruption, the amount of time that businesses spend dealing with government regulation, poor power availability, etc. In a survey of 2,676 firms, access to finance $(33.1 \%)$, access to electricity $(27.2 \%)$ and the level of corruption $(12.7 \%)$ were the most ranked obstacles for business owners. By employing the World Bank Enterprise Survey, this paper presents and analyses the business environment challenges at the national level.
\end{abstract}

Keywords: SMEs, Enterprise, Productivity, Sustainability and African Business Environment.

\section{Introduction}

Small and Medium Enterprises (SMEs) play a significant role in the economic development and poverty reduction of many nations. SMEs are found in a wide array of business activities. These ranges from the single artisan producing agricultural implements for the village market, the coffee shop at the corner, the internet café in a small town to a small sophisticated engineering or software firm selling in overseas markets and a medium-sized automotive parts manufacturer selling to multinational automakers in the domestic and foreign markets (OECD, 2014). The increase in attention in SMEs has become more important since the economic impact of the 2007/2008 financial crisis on economies globally (Igwe, 2016; Igwe, Onjewu and Nwibo, 2018). With globalization, developing countries are becoming increasingly interdependent for international exchange of goods and services, labour, innovation and technology. This phenomenon demands that all economies become proactive, identify opportunities that offer comparative advantages and take innovative steps to economic growth, job creation and prosperity.

The development of Nigeria as an emerging economic power in Africa is one of the highlights of the impact of globalization. African Economic Outlook (AEO, 2012) maintain that Nigeria's economic growth averaged about $7.4 \%$ annually from 2000 to 2010 and remained robust in 2011 at $6.9 \%$, driven by the non-oil sector, particularly

${ }^{1}$ University of Lincoln, UK

${ }^{2}$ University of South Wales, UK

${ }^{3}$ Nottingham Trent University, UK

${ }^{4}$ Coventry University, UK 
telecommunications, construction, wholesale and retail trade, hotel and restaurant services, manufacturing and agriculture. Despite the strong economic growth, poverty levels in Nigeria have climbed - a paradox that may be partly explained by the structure of Nigeria's low-productivity economy (with a large informal sector), which is not geared to job creation (The Economist Intelligence, 2012). As a result, about $60 \%$ of Nigerian population live on less than 1 US dollar (USD) per day and the unemployment rate in 2011 was $23.9 \%$, up from $21.1 \%$ in 2010 (AEO, 2012).

In 2016, Nigerian economy dipped into recession for the first time in more than two decades, attributed to a series of shocks, including the continued decline in oil prices, foreign exchange shortages, sharp reduction in oil production, power shortages, and insecurity in the North and Niger Delta regions (African Economic Outlook, 2017). As Nigerian economy continues to face serious macroeconomic challenges, the Central Bank of Nigeria (CBN) pursue a contractionary monetary policy stance to enhance economic recovery. In response to the falling economy, the Nigeria government embarked on promoting entrepreneurship and diversification of its economy through the non-oil sector. In the past few years, Nigerian governments have initiated entrepreneurial funds to stimulate the creation of new businesses among youths and women population. Examples of such schemes include the 'YouWin Enterprise Initiative' of 2011 - 2014 and the Social Intervention Programme of the current administration for which about half a trillion was allocated in the 2016 budget.

These initiatives have received significant boost in area of investments in the non-oil commercial, industrial and agricultural enterprises through private investments and International Development programmes (e.g. World Bank-assisted projects, the FADAMA III Additional Financing, etc.). FADAMA III AF project which emerged from the Agricultural Transformation Agenda (ATA) in 2013 focuses on improving the productivity of clusters of farmers engaged in the cultivation of staple foods such as rice, cassava and sorghum in eight selected states of Anambra, Enugu, Kano, Sokoto, Lagos, Ogun, Niger and Kogi. The World Bank (2013) announced that over three thousand farmers have benefited from Commercial Agriculture Development Project (CADP) in Kano State worth over N209 million. The World Bank (2017) state that the development objective of the Agro-Processing, Agricultural Productivity Enhancement and Livelihood Improvement Support Project for Nigeria is to enhance agricultural productivity of small and medium scale farmers and improve value addition along priority value chains in the participating States.

The objectives of this paper are to examine the factors that affect productivity and growth of SMEs and entrepreneurship in Nigeria. It contributes to knowledge on the business environmental issues and challenges in Nigeria. We examine five main determinants of productivity, which include education of the labour force, access to infrastructure, access to finance, size of firms and other business climate variables. The dimensions of business climate variables are insecurity, bribe or corruption, the amount of time that businesses spend dealing with government regulation, practices of informal activities, tax and trade regulations, etc. The remainder of the paper is structured as follows: Next section explores theoretical review on productivity and investment climate in Nigeria. This is followed by description of the methodology, analysis and summary of results. The last section concludes the paper and present implication for future research. 


\section{Literature Review}

The literature provides a consensus that good business environment fosters firms' growth, productivity and development, while adverse business environment increases firms' transaction costs and constraints on their development (Herrera and Kouamé, 2017). The business environment refers to a set of factors, policies and institutions that shape the opportunities and incentives for firms to invest productively, create jobs and expand (Aterido et al. 2011; World Bank., 2005; Igwe, 2016). Igwe, et al. (2017) identified five major institutional barriers in Nigeria as follows: (i) an ineffective credit and financial system; (ii) corruption, political instability and an inefficient legal system; (iii) poor infrastructure; (iv) lack of quality education and (v) religion, traditions and customs. These obstacles add to the usual challenges that SMEs face such as insecurity, bribery, the amount of time in dealing with government regulation, power unavailability and lack of market access. African is still at its earliest stage of economic development and this process is held back by several socio-economic, political and environmental constraints. Among these constraints are low skilled labour, lack of market information, poor access to financial services \& technology, and weak demand for goods and services due to widespread poverty - which leave SMEs at a competitive disadvantage in the global market place according to International Finance Corporation (IFC, 2008).

A stable macroeconomic environment is regarded as being conducive to long term economic development. Until the 1970s, macroeconomic policies in developing countries were mainly growth oriented national development strategies (Okojie, 2013). A broad developmental approach require that macroeconomic policies should be growthcentred with full employment as the ultimate objective (Ocampo and Vos, 2008). Wallace (2000) state macro-level instruments based on four characteristics necessary for Africa SMEs development as follows: Firstly, SMEs need a stable economy with financial discipline, prudent fiscal management and low inflation, tax and financial sector reform, exchange rates that reflect the strength of the economy and the privatization of state enterprises. Secondly, they need a competitive economy where prices and markets provide clear signals to producers and consumers, a regulatory framework favouring competition without unnecessary barriers to market entry, legal and property rights that facilitate the enforcement of contracts, and information and physical infrastructure (such as transport) that minimises transaction costs. Thirdly, they need global linkages based on openness to trade, investment, technology and ideas, low trade barriers, the relatively free movement of people and the encouragement of exports through a realistic exchange rate. Fourthly, they need investment in people in terms of health, education and nutrition, with emphasis on primary education and preventive health care.

Cervantes-Godoy and Dewbre (2010) provides a list of necessary factors that influences economic growth. These factors are access to raw materials and inputs, access to markets accommodated by a good transportation, marketing, processing and infrastructure, non-discriminatory tax and trade policy, high rates of investment in agricultural research and extension, a system of ownership rights that encourages initiative, employment creating SMEs, well-functioning institutions, good governance, etc. In the non-farm sector, the World Bank (2008) maintains that making agriculture 
more effective in supporting sustainable growth and reducing poverty starts with a favourable socio-political climate, adequate governance, and sound macroeconomic policies. Christiaensen and Todo (2008) observed that there are two phases as nations develop as follows: their economies restructure away from agriculture into manufacturing and services and people move from rural to urban communities. The process of agricultural development and pathways out of poverty, according to the World Bank requires defining an agenda for each country type, based on a combination of four policy objectives - forming a policy diamond as shown in Figure 1.

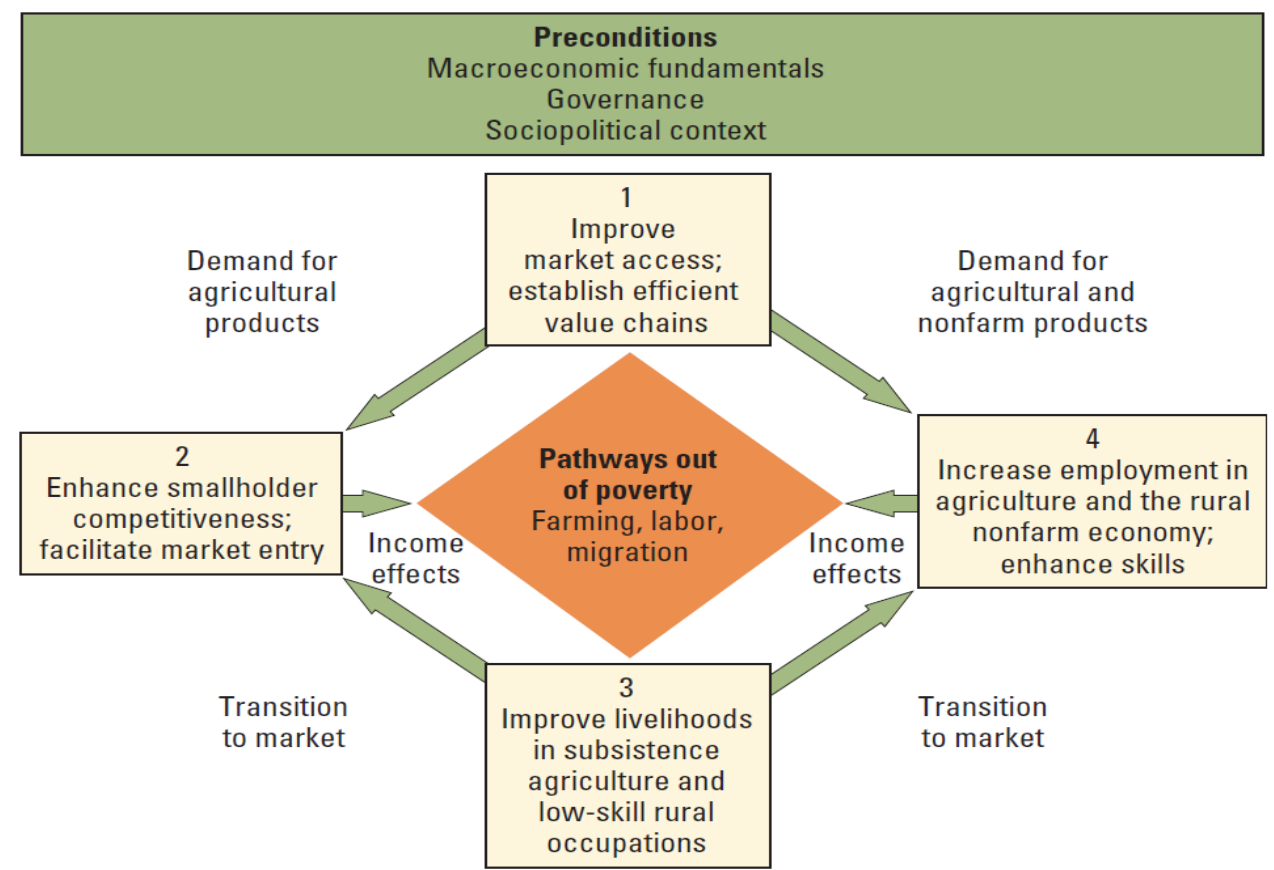

Figure 1. The four policy objectives of the agriculture-for-development agenda-policy diamond. Source: World Bank (2008, pp.19).

This paper explores five main determinants of investment and productivity which include age and size of firms, access to finance, access to infrastructure, education of the labour force and business climate variables. The dimensions of business climate variable are insecurity, bribery and corruption, the amount of time that businesses spend dealing with government regulation, poor transportation infrastructure and power availability, etc. It examines the effects of the factors and variables on productivity, entrepreneurship and economic growth.

\subsection{Age and Size of Firms}

A major indicator of performance of new ventures is their post-entry growth (Parker, 2004; Coad, 2014). Several studies have indicated that firm age is an important determinant of firm growth, with younger firms growing faster than older firms (Caves, 1998; Coad and Rao, 2008; Haltiwanger et al., 2013). However, the characteristics of new 
firm growth remain poorly understood (McKelvie and Wiklund, 2010) and there is still lack knowledge on how firm age is influencing firm growth rates over time (Coad, 2014). On one hand, the "Learning-by-doing models" (Arrow, 1962; Chang et al., 2002) suggest that older firms may benefit from their greater business experience, and therefore have more growth persistence than younger firms. On the other hand, older firms might suffer from a "liability of obsolescence" and a "liability of senescence" (Coad, 2014). Coad suggest lower growth persistence for old firms, since they have problems adapting their strategies to changing or current business conditions.

Gibrat's (1931) predict that size of firm is independent on growth rates. The literature provides array of studies focusing on the hypothesis whether firm growth is independent of firm size (Coad 2014; Parker et al., 2010). Some studies indicate that firm growth is characterized by positive autocorrelation rates (Dunne and Hughes, 1994) and others negative autocorrelation (Goddard et al., 2002; Coad and Hölzl, 2009). Coad and Hölzl (2009) found that the growth patterns of micro firms are strikingly different from the growth patterns of small, medium-sized and larger firms. The authors suggest that growing micro firms are subject to negative autocorrelation of annual growth rates, while larger growing firms usually display a positive autocorrelation suggesting that high growth episodes of larger firms stretch over a longer time horizon.

SMEs in Africa operate in the informal and formal sectors with the majority in the informal sector (Igwe, Newbery and Icha-Ituma, 2018). Liedholm (2001) state that if one defines the SMEs as those firms with $1-50$ workers, the upper end of the tail those with $10-50$ workers - constitute less than 2 percent of businesses in Africa. In African countries, most of the small-scale enterprises are mostly one-person or family owned, operating with one-person proprietor and unpaid family members or few employees (Igwe \& Icha-Ituma 2016a). Based on the World Bank Enterprise Surveys that collects business data in both formal and informal firms, La Porta and Shleifer (2014, pp. 113) provides a summary of characteristics that distinguish informal and formal businesses as follows:

- Informal businesses are much smaller than formal firms.

- On average formal firms employs 126 people, informal firms employ only four.

- Informal firms are much less productive, with productivity calculated as value added (sales net of expenditures on raw materials and energy) per employee.

- Informal firms add only $15 \%$ of the value per employee of formal firms, whereas, the ratio of value added by informal firms to that by formal firms ranges from 1 percent in Congo to $70 \%$ in Cape Verde.

- There is a sharp productivity difference between informal firms and formal firms of the same size, whereas productivity increases with size within the formal sector.

It has been suggested that the lack of SMEs growth is influenced by the fact that small and informal enterprises are reluctant to become large because being large requires being formal and thus becoming subject to excessive regulations (Sonobe et al., 2009). Using the World Bank benchmarking for measuring the size of the economy, ILO (2006) estimates that informal sector average size as a percentage of Gross Domestic Product (GDP) in sub-Saharan Africa ranges from under 30\% in South Africa to 60\% in Nigeria, 
Tanzania and Zimbabwe. Financial inclusion encourages investment by reducing liquidity constraints and therefore affects firm size, competition, and industrial structure (Beck et al. 2005). Studies by the IFC show that nearly $96 \%$ of Nigerian businesses are SMEs compared to $53 \%$ in the US and $65 \%$ in Europe and contribute approximately $1 \%$ of GDP compared to $40 \%$ in Asian countries and $50 \%$ in the US or Europe (OyelaranOyeyinka, 2007).

Despite the high number of SMEs in Nigeria, they face many challenges that affect their growth and survival and productivity. As a result, most SMEs in Nigeria die within their first five years of existence, a smaller percentage goes into extinction between the sixth and tenth year while only about five to ten percent survive, thrive and grow to maturity (Aremu and Adeyemi, 2011). Agwu and Emeti (2014) identified many factors contributing to this premature death of SMEs as follows: insufficient capital, irregular power supply, infrastructural inadequacies (water, roads etc.), lack of focus, inadequate market research, lack of succession plan, inexperience and lack of proper book keeping, inability to separate business and personal finances, etc.

\subsection{Access to Finance}

Access to finance is one of the major business concerns and youth-specific obstacles in Africa (GEM, 2014). Financial exclusion refers to a situation where the poor and other disadvantaged groups are unable to access formal financial services, owing to their perceived vulnerability (Mishra, Igwe and Lean, 2014). Financial constraints are more pervasive in agriculture and related activities than in many other sectors, reflecting both the nature of agricultural sector and the average size of firms (World Bank 2008). In a survey of 6,000 households in Indian, results showed that $87 \%$ of the marginal farmers surveyed had no access to formal credit, and $71 \%$ had no access to a savings account in a formal financial institution (World Bank, 2008). Financial issues top the list of disincentives $(55 \%)$ for young Nigerians with desire to run their own businesses (GEM, 2013). The financial service landscape of Nigeria is one that shows a lack of access to a range of affordable, safe and reliable financial services (Igwe, Newbury and Icha-Ituma, 2018). The Central Bank of Nigeria (CBN, 2005) indicate that the formal financial system provides services to about $35 \%$ of the economically active population while the remaining 65\% are excluded from access to financial services in Nigeria. As a result, households have traditionally patronized informal credit lenders some of whom charge higher interest rates and give short-term small loans (Igwe, 2016; Igwe and Icha-Ituma, 2016b).

\subsection{Access to Infrastructure}

The relationship between infrastructure and economic growth is a major focus of development literature (Ayogu, 2007; DFID, 2011 \& 2012; Dorosh et al., 2010; Dorward et al. 2004; Estache et al. 2002; Estache \& Vaglisaindi, 2007; Khander \& Koolwall 2010; Krishna \& Shariff, 2011; NEPAD, 2002; Reardon, 2001; World Bank, 2010). These studies support the idea that under the right conditions, infrastructure development play a major role in increasing productivity, promoting economic growth and poverty reduction. Onyeiwu and Liu (2011) show that in Bangladesh, a 1\% increase in households with access to electricity and paved roads in the villages led to $0.8 \%$ 
increase and 33\% in total per capita income respectively. The Nigerian power sector's operational efficiency and cost recovery is among the worst in Africa, supplying about half of what is required, with subsequent social costs of about 3.7\% of GDP (World Bank, 2011). In the transport sector, Nigeria's road networks are in poor condition from lack of maintenance, and the country has a poor record on air transport safety (World Bank, 2011). As in most part of Africa, mobility is severely constrained by lack of transport infrastructure (Bryceson, Mbara and Maunder 2003). To improve the productivity, profitability and competitiveness of SMEs will require improvement and investment in public infrastructure such as roads, schools, hospitals, electricity, transportation and water (Igwe, 2016).

\subsection{Education of the Labour Force}

There has been much debate on the effect of education of the labour force in the economic development and poverty reduction of nations. Some studies have found that the effects of education on the probability of being poor to be very strong relationship (Appleton, 1997; Oxaal, 1997). Based on the findings from studies in Uganda and Russia, Aikaeli (2010) maintains that education allows people to adapt more easily to both social and technical changes in the economy and to changes in the demand for labour. Education is often the most important foundation for people to pursue opportunities in new business, seek higher employment and migrate (World Bank, 2008). Nigeria is noted for its poor quality of primary education as well as low levels of tertiary enrolment (GEM, 2014). About 40\% of Nigerian children aged 6-11 years (about 4.7 million children of primary school age) do not attend any primary school with the Northern region recording the lowest school attendance rate in the country, particularly for girls (UNICEF, 2005). The problem in Nigeria is not just poor levels of school completion rates but that of skills mismatch (GEM, 2014).

\subsection{Other Business Climate Variables}

Associated investment climate and productivity has been examined in detail by several authors (e.g. De Rosa et. al., 2013; Klapper et al., 2006). Related business constraints that affect SMEs in Nigeria centre on the political, social and legal ground rules within which businesses operate, including stable government, time it takes in dealing with government procedures, property rights and taxation, etc. Regionalism, tribalism, sectionalism and ethnicity are other major problems facing Nigerian political environment (Ochulor, 2011). Among the major institutional problems that have impeded sustainable development in Nigeria is corruption which appears embedded in the culture (Faleye, 2013; Keeper, 2012). Aidis et al. (2012) argue that corruption constrains entrepreneurship by deterring entrepreneurs unwilling to engage in corrupt practices and encouraging unproductive forms of entrepreneurship.

Fear of failure is the percentage of people who perceive opportunities in the area in which they live yet indicate that fear of failure would prevent them from starting a business (GEM, 2014). Fear of failure can be influenced by intrinsic personality traits, as well as by societal norms, cultural barriers, government procedures, taxation and other regulations. GEM (2002) suggestions to policy makers to improve business environmental conditions in Sub-Saharan Africa include improvement in the physical 
infrastructure - power, transportation, water and broadband internet, especially in the more rural areas, reduce bureaucracy and red tape in starting a business. Make it quicker and less costly; implement incentives to encourage entrepreneurs to start new businesses and companies to invest in small businesses through internships and apprenticeships, etc.

World Bank Doing Business focuses on regulations and regulatory processes involved in setting up and operating a business. It analyses those that address asymmetries information (such as credit market regulations), those that balance asymmetries in bargaining power (such as labour market regulations) and those that enable the provision of public goods or services (such as business or property registration). The ease of doing business ranking ranges from 1 to 189. As shown in Table 1, South Africa has the best ranking of 73, followed by Uganda 122, Burkina Faso 143, Nigeria 169 and Angola 181. In contrast, in terms of getting credit ranking, Uganda is ranked highest on 42, followed by South Africa 59, Nigeria 60, Burkina Faso 133 and Angola 181. Nigerian ranking has seen changes in 2017 by one or two points for most of the indicators except ease for getting credit where the ranking has improved significantly by 16 points from 60 in 2016 to 44 .

Table 1. Doing Business Ranking of selected Sub-Saharan African countries.

\begin{tabular}{lccccc}
\hline & Nigeria & Angola & Burkina Faso & Uganda & South Africa \\
\hline GNI per capita (US\$) & 2,950 & 5,300 & 710 & 660 & 6,800 \\
Ease of doing business rank (1-189) & 169 & 181 & 143 & 122 & 73 \\
- Starting a business (rank) & 139 & 141 & 78 & 168 & 120 \\
- Time (days) & 30.8 & 36 & 13 & 27 & 46 \\
- Cost (\% of income per capita) & 31.7 & 22.5 & 43.5 & 39.7 & 0.3 \\
Getting Credit (rank) & 60 & 181 & 133 & 42 & 59 \\
Getting electricity (rank) & 182 & 166 & 183 & 167 & 168 \\
- Time (days) & 181.2 & 145 & 158 & 86 & 226 \\
\hline
\end{tabular}

Source: Igwe and Icha-Ituma (2016a, pp.13).

\section{Methodology, Analysis and Results}

This paper employs secondary data from World Bank Enterprise Survey to explore business environmental challenges and productivity issues in Nigeria. The Enterprise Survey was used to ensure statistical representativeness at the national level. The Enterprise Survey use standard survey instruments to collect firm-level data on the business environment from business owners and top managers aggregated to the country level. Data provides a description of private firms and an estimate of how some of the attributes of the average firms are distributed across the population of firms collected through interview of owners and top managers of 2, 676 small, medium and large firms in Nigeria. The survey covers a broad range of topics including access to finance, corruption, infrastructure, crime, competition, labour, obstacles to growth, and performance measures (Enterprise Survey, 2017). The data are available to download by researchers and include answers from all the survey questions as well as country-specific questions. 


\subsection{The World Bank Enterprise Data}

The Enterprise survey collect firm-level data on the business environment from several Nigerian States. The number of firms in each subnational location level in the 2014 survey were Abia (124), Abuja (151), Anambra (149), Cross River (136), Enugu (124), Gombe (126), Jigawa (123), Kaduna (138), Kano (200), Katsina (125), Kebbi (133), Kwara (124), Lagos (282), Nasarawa (130), Niger (124), Ogun (130), Oyo (119), Sokoto (115), Zamfara (123). The Enterprise Surveys collect information on the non-agricultural formal private economy. Tables 2 summarize the sample structure of the Investment Climate Survey composition by size and sector. About $98 \%$ and $93 \%$ of the firms surveyed in 2007 and 2014 were small/micro and medium firms respectively. Figure 2 shows the number of firms in each business sector level (5 sectors in 2007 and 16 sectors in 2014).

Table 2. Summary of the sample composition.

\begin{tabular}{lcc}
\hline Data Details & 2007 & 2014 \\
\hline Size of firms & 1419 & 1753 \\
- Micro/Small (<20 employees) & 426 & 734 \\
- Medium (20-99 employees) & 46 & 189 \\
- Large (100+ employees) & & \\
Ownership & 1874 & 2162 \\
- Domestically-owned & 17 & 514 \\
- Foreign-owned & 1452 & 2123 \\
- Firms without female participation in ownership & & \\
Trade Orientation & 24 & 461 \\
- Exporters & 1867 & 2215 \\
- Non-exporters & 1891 & 2676 \\
Total Number of firms & & \\
\hline
\end{tabular}

Source: Authors' calculations based on Panel data from World Bank Enterprise Survey.

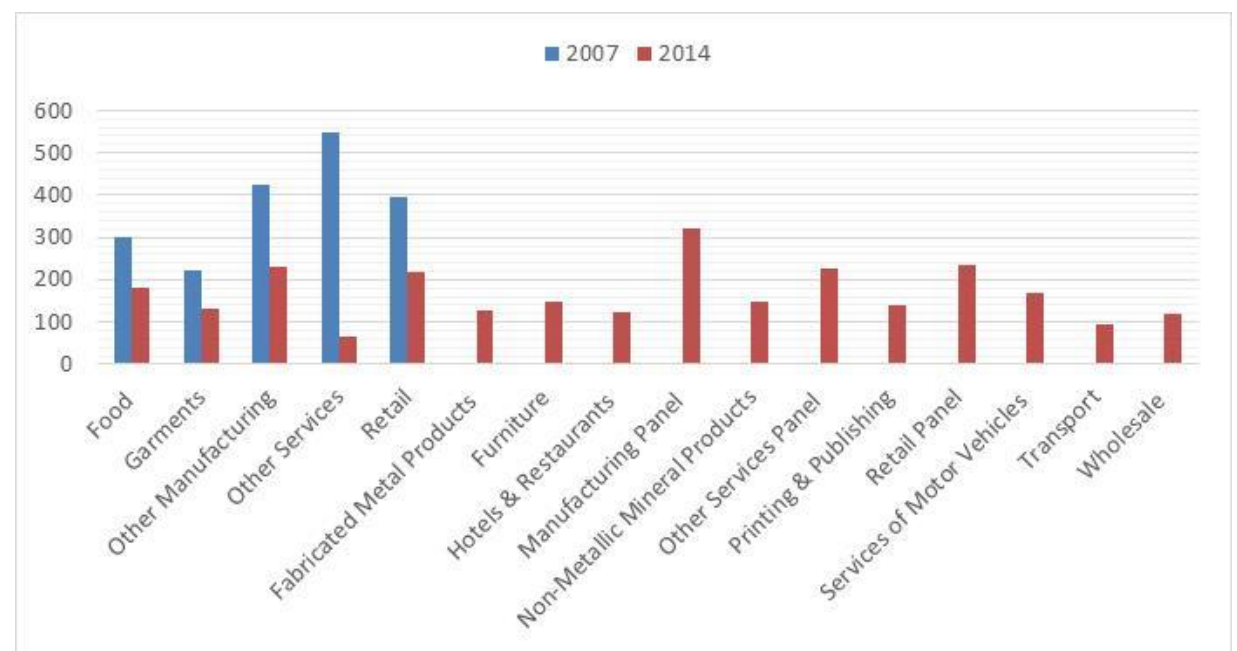

Figure 2. Number of firms in each business sector level.

Source: Authors' calculations based on Panel data from the World Bank Enterprise Survey. 


\subsection{Distribution of Firms by Age}

The effect the business environment can have on business may depend on firms' experience and longevity. Age of firm indicator measures the number of years that a firm have been in operation. Small firms are usually new in relation to years of operation. As shown in Table 3, large firms have the highest years if operation (24.9 years) followed by Medium firms (17.9 years) and small firms (15.1 years). These indicators were employed to assess determinant of the effect of regulations on the firm and the level of exposure of the firm to external factors, such as corruption, access to finance, and technology. As Coad (2014) noted, older firms and young firms may differ in their ability to successfully adapt their strategies to changing business conditions. As shown in Table 3, the percentage of firms with female top manager was highest in small firms $(16.0 \%)$ while firms with female participation in ownership was highest in large firms $(24.2 \%)$, while foreign firms were highest with large firms $(9.4 \%)$.

Table 3. Average Firm Indicators 2014.

\begin{tabular}{lccccc} 
& \multirow{2}{*}{ Nigeria } & \multicolumn{3}{c}{ Small } & \multicolumn{3}{c}{ Medium Large Sub-Saharan } \\
& & Firms & Firms & Firms & Africa \\
\hline Age (years) & 15.9 & 15.1 & 17.9 & 24.9 & 14.2 \\
\% of Firms with Female Top Manager & 13.9 & 16.0 & 5.7 & 6.0 & 15.3 \\
\% of Firms with Female Participation in Ownership & 16.2 & 16.8 & 12.2 & 24.2 & 36.0 \\
Private Domestic (\%) & 70.2 & 72.9 & 58.2 & 71.8 & 78.4 \\
Private Foreign (\%) & 3.1 & 2.8 & 3.2 & 9.4 & 13.3 \\
Government/State (\%) & 2.5 & 2.2 & 3.2 & 6.2 & 0.6 \\
Other (\%) & 24.3 & 22.0 & 35.4 & 12.6 & 7.8 \\
\hline
\end{tabular}

Source: Authors' calculations based on World Bank Enterprise Survey Data (2014).

\subsection{Access to Finance}

The Enterprise Surveys provide indicators of how firms finance their operations and the characteristics of their financial transactions, which compares the relative use of various sources to finance. About $53.1 \%$ of firms and $33.1 \%$ of firms identified access/cost of finance as a major constraint to business in 2007 and 2014 respectively (as shown in Table 4). Lack of access to finance and credit opportunities make it difficulties in meeting short-term payments and longer-term investments. The use of banks to finance investments is a basic indicator of access to credit. There was an improvement from $1.3 \%$ in 2007 to $3.4 \%$ in 2014. Excessive reliance on internal sources of capital by firms that wish to invest or expand their output is a sign of financial exclusion. About $65 \%$ of economically active population are excluded from access to financial services in Nigeria (CBN, 2005). Another set of indicators focuses on the use of bank loans and it quantifies the burden imposed by loan requirements, measured by collateral levels relative to the value of the loans. The values have risen from $138.8 \%$ in 2007 to about $227.7 \%$ in 2014 . Excessive demand for high collateral are likely to constrain investment opportunities. 
Table 4. Access to finance by Nigerian firms.

\begin{tabular}{|c|c|c|c|c|c|c|c|c|}
\hline & \multicolumn{2}{|c|}{ All firms } & \multicolumn{2}{|c|}{$\begin{array}{l}\text { Small } \\
\text { Firms }\end{array}$} & \multicolumn{2}{|c|}{$\begin{array}{l}\text { Medium } \\
\text { Firms }\end{array}$} & \multicolumn{2}{|c|}{$\begin{array}{l}\text { Large } \\
\text { Firms }\end{array}$} \\
\hline & 2007 & 2014 & 2007 & 2014 & 2007 & 2014 & 2007 & 2014 \\
\hline $\begin{array}{l}\% \text { of Firms Identifying Access/cost of } \\
\text { Finance as a Major Constraint }\end{array}$ & 53.1 & 33.1 & 59.3 & 34.3 & 34.8 & 31.4 & 10.2 & 6.9 \\
\hline Internal Finance for Investment $(\%)$ & 92.8 & 52.5 & 92.8 & 57.3 & 92.2 & 39.7 & 94.5 & 69.1 \\
\hline Bank Finance for Investment ( $\%)$ & 1.3 & 3.4 & 1.1 & 2.7 & 1.6 & 5.1 & 4.6 & 4.1 \\
\hline$\%$ of Firms with Bank Loans & 3.8 & 11.8 & 2.9 & 12.3 & 6.0 & 8.1 & 14.7 & 15.4 \\
\hline $\begin{array}{l}\text { Value of Collateral Needed for a Loan }(\% \\
\text { of the Loan Amount) }\end{array}$ & 138.8 & 227.7 & 146.1 & 222.5 & 104.2 & 227.5 & 194.4 & 286.1 \\
\hline
\end{tabular}

\subsection{Access to Infrastructure}

The Enterprise surveys captures a set of indicators that evaluates the efficiency of infrastructure services by quantifying the delays in obtaining electricity, water, and telephone connections. It notes that service delays impose additional costs on firms and may act as barriers to entry and investment. A strong infrastructure provides access to electricity, roads, railways, water, communication technology, etc. that enhances the competitiveness of an economy and a conducive business environment. Ineffective electricity supply can increase costs, disrupt production, and reduce profitability. Poor road network limit transport system, increase cost of distribution leading to high prices of goods and low demand and reduced profitability. The World Bank (2010) note that under the right conditions, infrastructure play a major role in increasing productivity and promoting economic growth. The percentage of firms identifying electricity as a major constraint was $75.9 \%$ in Nigeria and $48.1 \%$ in the Sub-Saharan African region in 2007 (Enterprise Surveys, 2014). As shown in Table 5, all the indicators considered have increased in terms of percentage of problems as identified by the 2007 survey when compared to 2014 values. These figures were higher than the Sub-Saharan African except for delays in obtaining electrical and water connections (in days).

Table 5. Access to infrastructure

\begin{tabular}{lcccc}
\hline & \multicolumn{2}{c}{ Nigeria } & \multicolumn{2}{c}{ Sub-Saharan Africa } \\
\hline & 2007 & 2014 & 2007 & 2014 \\
Number of Power Outages in a typical Month & 26.7 & 32.8 & 13.7 & 8.3 \\
Value Lost due to Power Outages (\% of Sales) & 8.9 & 11.2 & 5.9 & 5.4 \\
Delay in obtaining an Electrical Connection (days) & 7.7 & 9.4 & 34.8 & 29.3 \\
Delay in obtaining a Water Connections & 11.3 & 12.4 & 40.4 & 32.2 \\
\hline
\end{tabular}

Source: Authors' calculations based on Panel data from the World Bank Enterprise Survey.

\subsection{Education, Work force and Innovation}

The Enterprise Surveys collects data on composition of the firm's workforce by type of contract and gender as well as the use of Quality Certification, information and communications technologies (ICT) in business transactions. The average number of permanent - full time workers reduced from 16.2 in 2007 to 15.8 in 2014 and the 2014 value was far below the Sub-Saharan of 30.9 (Table 6). The average number of female workers increased from 16.9 in 2007 to 24.3 in 2014. The average permanent - full time 
workers in 2014 across the three sizes of firms showed that small firms (8.9), medium firms (331) and large firms (138.9). In terms of percentage of firms using email to communicate with Clients/suppliers in 2014, small firms (19.0\%), medium firms (35.4\%) and large firms $(78.0 \%)$. The percentage of firms using the Web to Communicate with Clients/suppliers in 2014 was small firms (14.8\%), medium firms (48.0\%) and large firms (69.3\%).

Table 6. Workforce and Innovation

\begin{tabular}{lcccc}
\hline & \multicolumn{3}{c}{ Nigeria } & \multicolumn{2}{c}{ Sub-Saharan } \\
& & Africa \\
\hline & 2007 & 2014 & 2007 & 2014 \\
Average Number of Skilled Production Workers & 12.2 & NA & 32.8 & NA \\
Average Number of Temporary Workers & 2.6 & 1.6 & 28.4 & 6.4 \\
Average Number of Permanent, Full Time Workers & 16.2 & 15.8 & 57.7 & 30.9 \\
\% of Full Time Female Workers & 16.9 & 24.3 & 20.7 & 29.3 \\
\% of Firms with Internationally Recognized Quality Certification & 8.5 & 7.1 & 12.2 & 15.1 \\
\% of Firms using the Web to Communicate with Clients/suppliers & 9.7 & 22.3 & 18.9 & 33.3 \\
\% of Firms Using Email to Communicate with Clients/suppliers & 26.0 & 23.5 & 44.1 & 60.5 \\
\hline Soury
\end{tabular}

Source: Authors' calculations based on Panel data from the World Bank Enterprise Survey.

\subsection{Other Business Climate Variables}

In the World Bank Enterprise Survey, business owners and top managers were presented with a list of 10 business environment obstacles and asked to choose the biggest obstacle to their business. Access to finance, access to electricity and the level of corruption were the most ranked obstacles for firms with $33.1 \%, 27.2 \%$ and $12.7 \%$ respectively (Figure 3.). Corruption in the public service creates an unfavourable business environment by undermining the operational efficiency of firms and raising the costs of doing business. Also, corruption constrains entrepreneurship by deterring entrepreneurs unwilling to engage in corrupt practices and encouraging unproductive forms of entrepreneurship (Igwe et al., 2017). The Enterprise indicators measures a composite index of corruption, the Graft Index shows Nigeria (29.5\%) and Sub-Saharan Africa $(21 \%)$, reflecting the proportion of times a firm was asked or expected to pay a bribe when soliciting six different public services, permits or licenses.

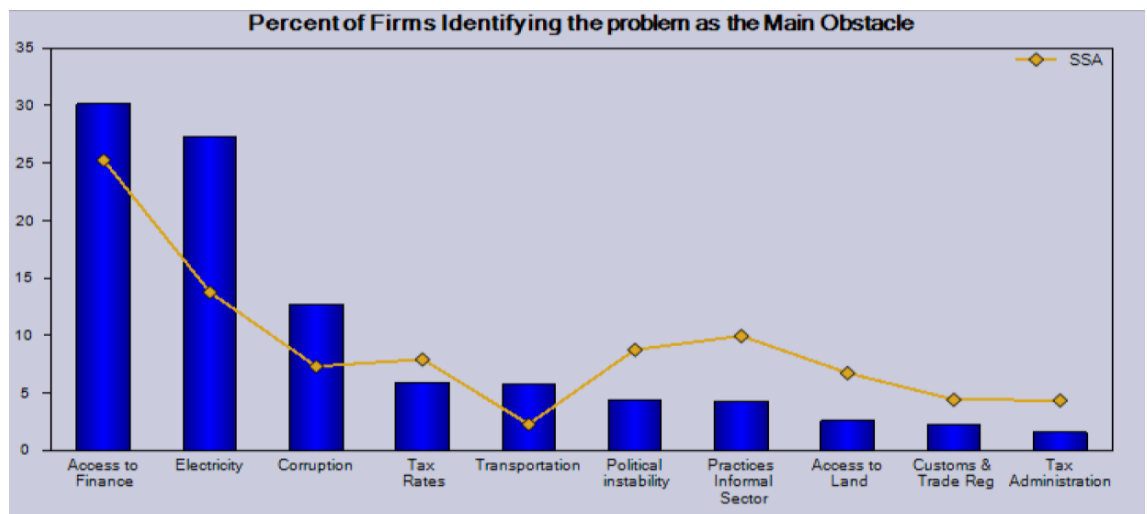

Figure 3. Other business problems / obstacles.

Source: World Bank Enterprise Survey - Nigerian Country Profile (2014: pp. 4) 
Other business environment captured in the Enterprise Surveys include corruption; regulations, taxes, and business licensing; operational constraints faced by exporters and importers and quantifies the trade activity of firms; and effect of crime on firm sales, the extent to which entrepreneurs identify courts as fair, and the degree of informality in an economy. As shown in Table 7, while some of the indicators are on the decline, others are increasing when compared with 2014. For example, while percentage of firms expected to give gifts to get an operating license decreased from $40.3 \%$ in 2007 to $24.2 \%$ in 2014, percentage of firms expected to give gifts to get an import license increased from $33.3 \%$ in 2007 to $40.7 \%$ in 2014 (Table 7 ).

Table 7. Other Business Environment indicators

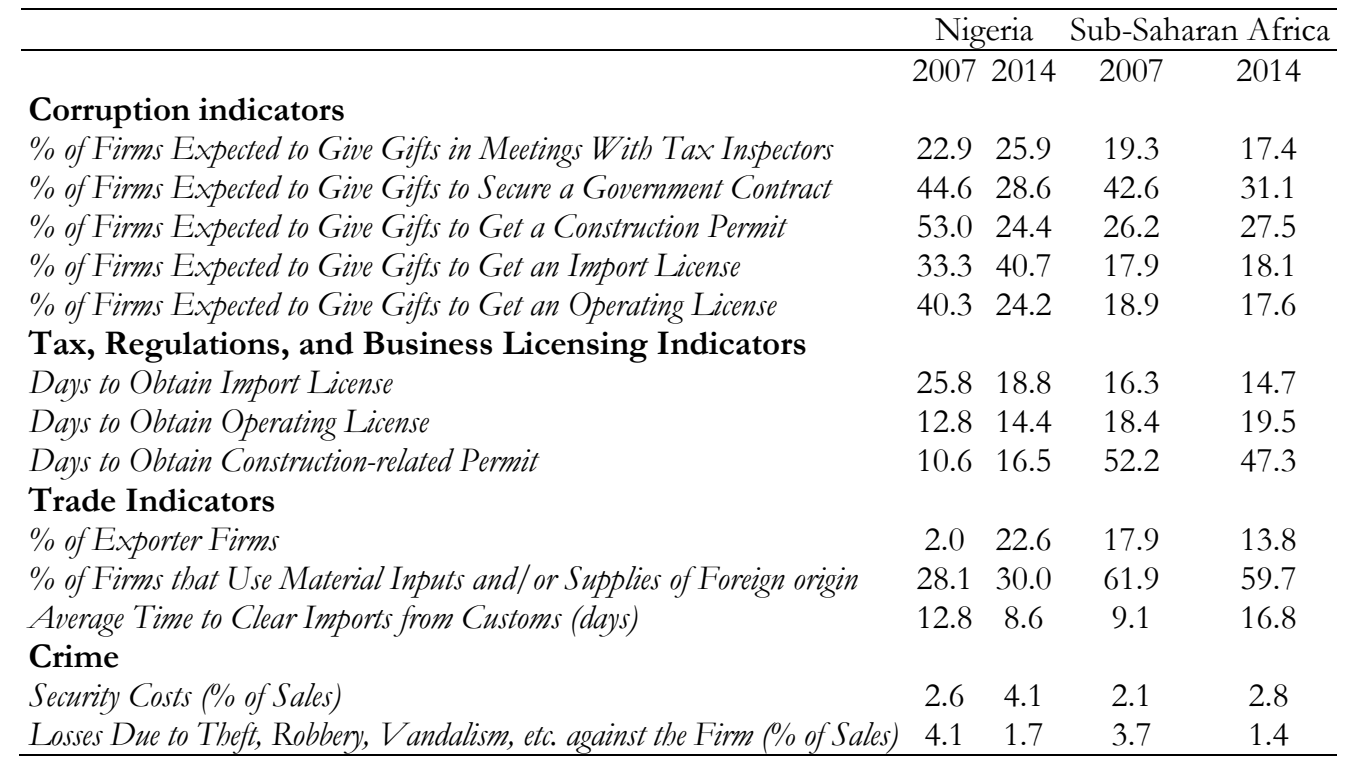

Source: Authors' calculations based on panel data from the World Bank. Enterprise Survey.

The Enterprise Surveys showed that the percentage of exporter firms in 2007 as follows: small firms (1.0\%), medium firms (4.2\%) and large firms (14.1\%). These values increased by 2014 as follows: small firms (22.6\%), medium (22.0\%) and large firms $(27.0 \%)$ as shown in Figure 4. The percentage of firms that use material inputs and/or supplies of foreign origin in 2007 were small firms $(32.1 \%)$, medium firms $(16.4 \%)$ and large firms (34.0\%) while in 2014 the figures were small $(26.3 \%)$, medium $(36.4 \%)$ and large firms $(72.4 \%)$ as shown in Figure 5. While exports among small and medium enterprises in 2007 has more than quadrupled by 2014, imports of materials and supplies from foreign firms by small enterprises has been declining as shown in Figure 5. However, the trend showed that imports by the medium and large firms has been on the increase. 


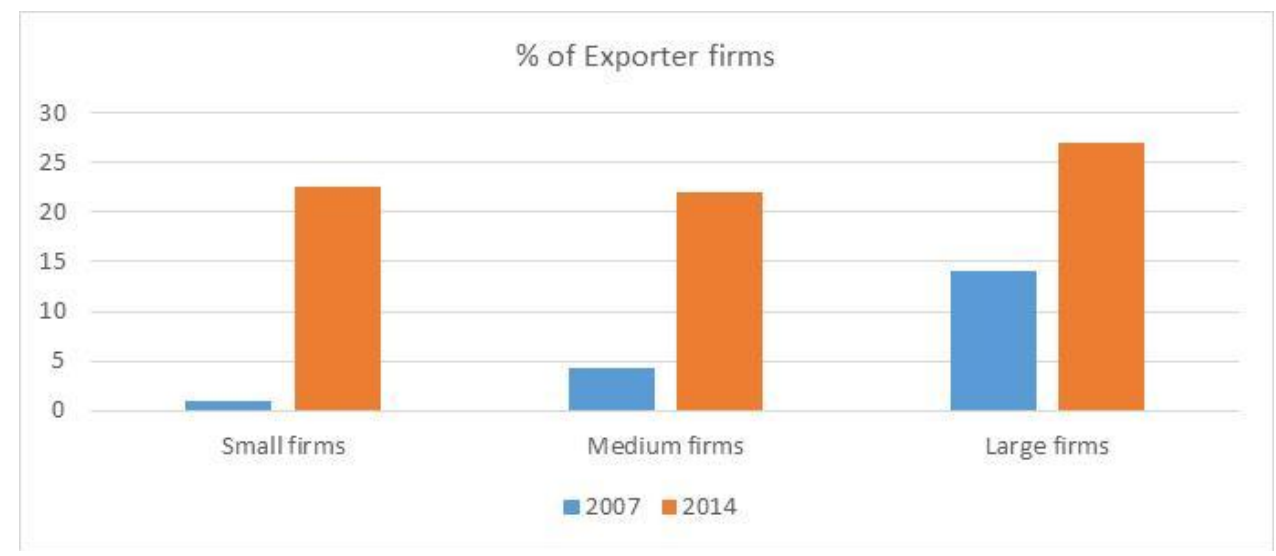

Figure 4. Other business indicators.

Source: Authors' calculations based on Panel data from the World Bank Enterprise Survey.

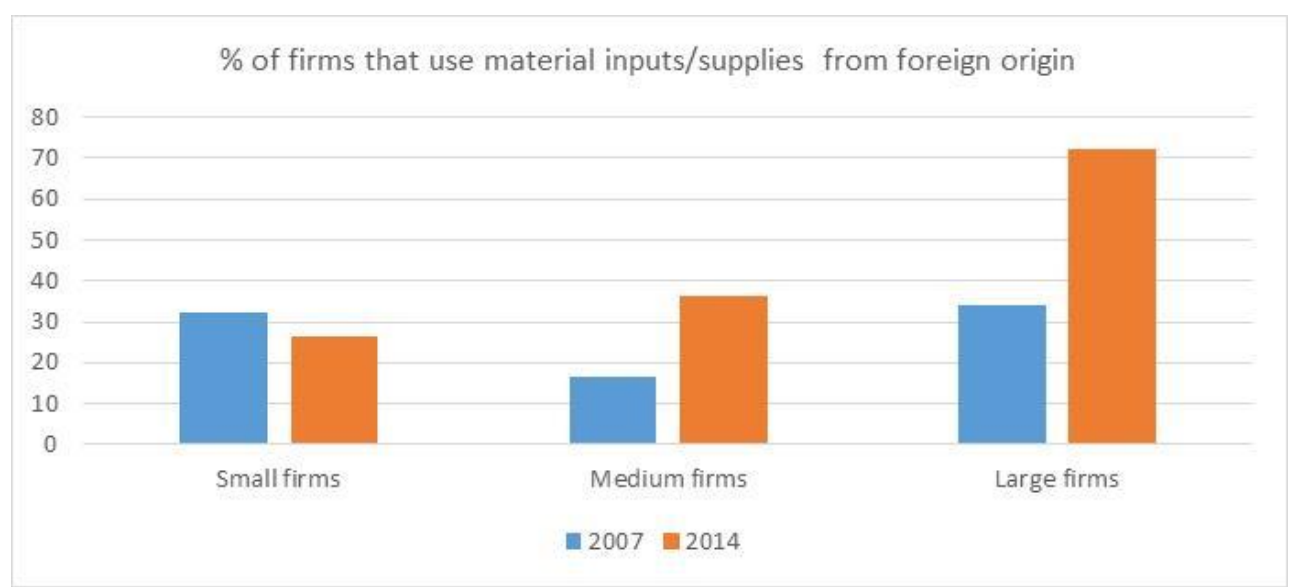

Figure 5. Other business indicators.

Source: Authors' calculations based on panel data from the World Bank Enterprise Survey.

The percentage of formality reflecting the number of firms formally registered when started operation in Nigeria is shown in Figure 6. About $57.7 \%$ of the small, medium and large enterprises in Nigeria were formally registered with the government in 2014 when they started operations. However, this figure is low when compared with the percentage of firms registered with government in the Sub-Saharan African region $(83 \%)$. The review of literature showed that majority of SMEs in Africa operate in the in the informal sector (Igwe, Newbery \& Icha-Ituma, 2018). The 'informal economy' refers to "all economic activities by workers and economic units that are - in law or in practice not covered or insufficiently covered by formal arrangements (ILO, 2014). Informality takes many forms in Nigeria such as unregistered small firms, street vendors, market traders, wholesalers and large un-registered firms that operate without government registration. 
$\%$ of firms formally registered when started operations

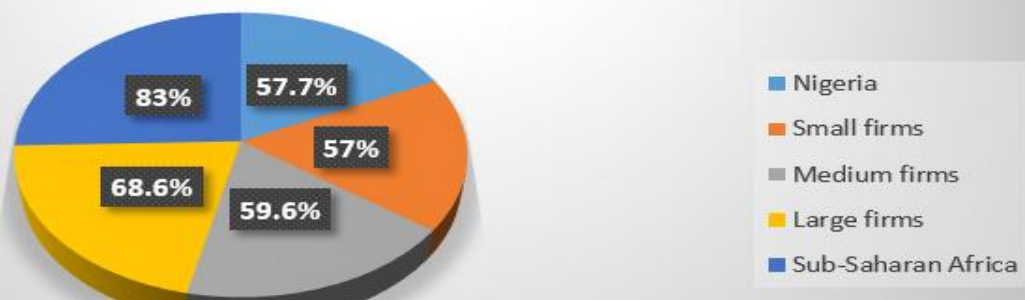

Figure 6. Percentage of formality

Source: Authors' calculations based on panel data from the World Bank Enterprise Survey.

\section{Conclusion and Implications for Future Research}

This paper examined the factors affecting productivity, growth of SMEs and Entrepreneurship in Nigeria. It explored literature on the business investment variables that include age and size of firms, access to finance, access to infrastructure, education of the labour force and business climate variables. It examined the effects of the factors and current trend in the Nigerian business environment. The paper contributes to knowledge on the business environmental issues and challenges in Nigeria intended to support those involved in SMEs promotion: policymakers who want to create the right conditions; non-governmental organisations who fund and support start-ups; academics and researchers exploring and applying the theories and paradigms that underpin SMEs, entrepreneurship and productivity. The attention that SMEs in Africa has received in recent years has been attributed to many reasons. First, the high rate of population growth requires investment to increase economic activities to address the problem of the high rate of unemployment in Africa. Second, increasing economic activities through promoting entrepreneurship increases income earning opportunities that offer the longterm path to poverty reduction - poverty incidence being major problem in many African countries. By employing secondary data from World Bank, this paper explored business environmental challenges and productivity issues in Nigeria at the national level. It provides a description of firm-level statistics and estimates of how some of the attributes of the average firms are distributed across Nigeria and business challenges. In the World Bank Enterprise survey of 2,676 firms in Nigeria, access to finance (33.1\%), access to electricity (27.2\%) and the level of corruption (12.7\%) were the most ranked obstacles for business owners.

Despite the contributions of this study, it has its limitations, which provide avenues for further research. Future research could focus on examining the determinants of firms' productivity through a modelling of firm growth (such as a stochastic process). The stochastic framework models the internal and external factors affecting the process of growth for the individual firm at the aggregate level. While some factors work to decrease productivity, others cause it to increase. It follows the cross-sectional analysis of firm growth (see for example Coad, 2014). The analysis could employ different measures of productivity: labour productivity per worker, value added per worker, and total factor 
productivity (TFP). For example, Herrera and Kouamé (2017) employed the TFP concept as an alternative measure of productivity at the firm level. By employing different measures of productivity, the robustness of the analysis and findings will be guaranteed.

\section{Appreciation}

Our Thanks goes to World Bank Enterprise Survey Team for giving us the permission to use the Enterprise Survey data for this publication.

\section{References}

African Economic Outlook (AEO, 2012). Nigeria. http://www.africaneconomicoutlook.org/en/countries/west-africa/Nigeria

African Economic Outlook (AEO, 2017). Nigeria Economic Outlook. African Development Bank Group. https://www.afdb.org/en/countries/west-africa/nigeria/nigeria-economic-outlook/

Agwu, M. O. and Emeti, C. I. (2014). Issues, Challenges and Prospects of Small and Medium Scale Enterprises (SMEs) in Port-Harcourt City, Nigeria. European Journal of Sustainable Development, 3, 1, 101-114 ISSN: 2239-5938 Doi: 10.14207/ejsd.2014.v3n1p101

Aidis, R., Estrin, S., Mickiewicz, T. (2012). Size matters: entrepreneurial entry and government. Small Business Economics 39, 119-139.

Aikaeli, J. (2010). Determinants of Rural Income in Tanzania: "An Empirical Approach" Research on Poverty Alleviation REPOA, 10/4.

Appleton, S. (1997). 'Leaping into the ark: some reflections on free primary education in Uganda', Centre for the Study of African Economies, University of Oxford.

Aremu, M. A. and Adeyemi, S. A. (2011). Small and Medium Scale Enterprises as A Survival Strategy for Employment Generation in Nigeria. Journal of Sustainable Development, Canadian Centre of Science and Education. Vol. 4(1): 200-2006.

Arrow, K.J. (1962). The economic implications of learning by doing. Review of Economic Studies, 29, 155-173.

Atérido, R., Hallward-Driemeier, M., \& Pages, V. (2011). Big Constraints to Small Firms' Growth? Business Environment and Employment Growth across Firms. Economic Development and Cultural Change, 59 (3), $609-647$.

Ayogu, M. (2007) "Infrastructure and Economic Development in Africa," Journal of African Economics, Vol.16, (1) $75-126$.

Barron, D. N., West, E., and Hannan, M. T. (1994). A Time to Grow and a Time to Die: Growth and Mortality of Credit Unions in New York, 1914-1990. American Journal of Sociology, 100(2): 381-421.

Beck, T., Demirgùç-Kunt, A., \& Maksimovic, V. (2005). Financial and Legal Constraints to Growth: Does Firm Size Matter? The Journal of Finance, 60 (1), 137-177.

Bryceson, D. F., Mbara, T. C. \& Maunder, D. (2003). Livelihoods, daily mobility and poverty in Sub-Saharan Africa, Transport Reviews: A Transnational Transdisciplinary Journal, 23:2, 177-196.

Caves, R. E. (1998). Industrial organization and new findings on the turnover and mobility of firms. Journal of Economic Literature, 36(4), 1947-1982.

Chang, Y., Gomes, J.F., \& Schorfheide, F. (2002). Learning-by-doing as a propagation mechanism. American Economic Review, 92, 1498-1520.

Coad, A. (2014). Firm Age and Growth Persistence, Innovation Forum VI-2014, Crisis, Innovation and transition, 1 - 3 October 2014, University of Paris Quest, Nanterre, La Defense.

Coad, A. and Hölzl, W. (2009). On the Autocorrelation of Growth Rates Evidence for Micro, Small and Large Firms from the Austrian Service Industries, 1975-2004. Industrial Competition Trade, (2009) 9:139-166

Coad, A., \& Rao, R. (2008). Innovation and firm growth in high-tech sectors: A quantile regression approach. Research Policy, 37(4), 633-648. 
De Rosa, G., Holger, G., and Nishaal , G. (2013). Corruption and productivity: Firm-level evidence. Jabrbücher für Nationalökonomie und Statistike, 235 (2), 115-138.

DFID (2011). Economic growth and private sector, Department for International Development, http://www.dfid.gov.uk/what-we-do/key-issues/Economic-growth-and-the-privatesector/Growth/

DFID (2012). Department for International Development, Growth Research News, December 2012.

Dorosh, P., Wang H., You, L. and E. Schmidt (2010). Crop production and road connectivity in SubSaharan Africa: a spatial analysis, The World Bank (2010) Policy Research Working Paper.

Dorward, A., F. Shengen, J. Kydd (2004). "Rethinking Agricultural Policy for Pro-Poor Growth" Natural Resources Perspective (ODI) Pp.1 - 4.

Dunne, P. and Hughes, A. (1994). "Age, size, growth and survival: UK companies in the 1980s," Journal of Industrial Economics, Vol. 42(2), pp. 115-140, 1994.

Economist Intelligence Unit (2012). Nigeria Country Report.

Enterprise Surveys (2017). (http://www.enterprisesurveys.org), The World Bank.

Estache, A. and Vaglisaindi, M. (2007). "Infrastructure for accelerated growth for Ghana: needs and challenges," unpublished manuscript.

Estache, A., Foster, V. and Woden, Q. (2002). "Accounting for Poverty in Infrastructure Reform: Learning from Latin America's Experience." WBI Development Studies, Washington, DC: The World Bank.

Faleye, O. A. (2013). Religious Corruption: A Dilemma of the Nigerian State, Journal of Sustainable Development in Africa, Volume 15, No.1, 2013. ISSN: 1520-5509.

Gibrat, R. (1931). Les inégalités économiques. Librairie du Receuil Sirey: Paris.

Global Entrepreneurship Monitor (GEM, 2012). African Entrepreneurship, Sub-Sabaran African Regional Report.

GEM (2013). Supporting Africa's Young Entrepreneurs: an investment in job creation and future prosperity for all, Global Entrepreneurship Monitor. http://www.gemconsortium.org/country-profile/93

GEM (2014). Africa's Young Entrepreneurs: Unlocking the Potential for a better future.

Goddard, J., Wilson, J., and Blandon, P. (2002). "Panel tests of Gibrat's law for Japanese manufacturing," International Journal of Industrial Organization, vol. 20(3), pp. 415-433, 2002.

Haltiwanger J., Jarmin R.S., and Miranda, J. (2013). Who creates jobs? Small versus Large versus Young. Review of Economics and Statistics, 95(2), 347-361.

Herrera, S. and Kouamé, W. (2017). Productivity in the Non-Oil Sector in Nigeria: Firm-Level Evidence. Policy Research Working Paper, 8145. Macroeconomics and Fiscal Management Global Practice Group, The World Bank Group, July 2017.

Igwe, P. A. (2016). Entrepreneurial Ecosystems \& the role of Government in promoting Entrepreneurship; Book Chapter in the Festschrift Textbook on Building Entrepreneurial Universities in a Developing Economy, Issues, Challenges and Prospects. Published December 2016.

Igwe, P. A. and Icha-Ituma, A. (2016a). Fostering Scale-up and ecosystem for entrepreneurship growth in Sub-Saharan Africa. Global Journal of Business and Management, [S.l.], Vol. 1, No. 1, p. 108-123.

Igwe, P. A. and Icha-Ituma, A. (2016b). Financial and Social Capital sustainability approach to rural livelihood in the Sub-Saharan African economy. Global Journal of Business and Management, [S.l.], Vol. 1, No. 1, p. 68-90.

Igwe, P. A., Newbery, R., Icha-Ituma, A. (2018). Entrepreneurship challenges and gender issues in the African informal rural economy. Book Title: Knowledge, learning and innovation, Research insights into cross sector collaboration. Editors: Vanessa Ratten, Carla Marques and Vitor Braga. Publisher: Springer International Publisher, 2017.

Igwe, P. A., Newbery, R., White, G. T. and Nihar, A. (2017). Keeping it in the family: Exploring Entrepreneurial Behaviour in Nigeria. The Institute for Small Business and Entrepreneurship (ISBE) Conference Paper, 8 - 9 November 2017, Belfast, UK.

Igwe, P. A., Onjewu, A. E. and Nwibo, S. U. (2018). Entrepreneurship and SMEs' productivity challenges in the sub-Saharan Africa. In: African entrepreneurship: challenges and opportunities for doing business. 272. Palgrave Macmillan. ISBN 9783319736990.

ILO (2006). The Impact of Globalization on the Informal Sector in Africa, International Labour Organization, Report VI, ILO, Geneva. 
ILO (2014), Transitioning from the informal to the formal economy, International Labour Conference $103^{\text {rd }}$ Session 2014, Report V (1). International Labour Office, Geneva.

International Finance Corporation (IFC, 2008). Supporting Entrepreneurship at the Base of the Pyramid through Business Linkages, IFC.

Keeper, D.G. (2012). "Systemic Corruption in Nigeria: A threat to Sustainable Development". Proceedings of the 1st International Technology, Education, Environment Conference. A Journal of African Society for Scientific Research (ASSR), 1 (1) 172-179.

Kandker, S. R. and Koolwall, G. B. (2010). How Infrastructure and Financial Institutions Affect Rural Income and Poverty: Evidence from Bangladesh. Journal of Development Studies, Vol.46, No.6, pp.1109 - 29 .

Klapper, L., Laeven, L., \& Rajan, R. (2006). Entry Regulation as a Barrier to Entrepreneurship. Journal of Financial Economics, 83 (3), 591-629.

Krishma, A. and Shariff, A. (2011). The Irrelevance of National Strategies? Rural Poverty Dynamics in States and Regions of India, 1993-2005. World Development, Vol.39, No.4: 533-549.

La Porta, R. and Shleifer, A. (2014). Informality and Development. Journal of Economic Perspectives, Volume 28, Number 3, Summer 2014. Pages 109-126.

Liedholm, C. (2001). Small Firm Dynamics: Evidence from Africa and Latin America.

McKelvie A., \& Wiklund, J. (2010). Advancing firm growth research: a focus on growth mode instead of growth rate. Entrepreneurship Theory and Practice, 34(2), 261-288.

Mishra, A., Igwe, P., Lean J. and Megicks, P. (2014). Book Chapter on Supporting Micro and Small Enterprises, The Routledge Companion to Financial Services Marketing, Routledge (Taylor \& Francis Group). http://www.routledge.com/books/details/9780415829144/ Published December 2014.

NBS (2010). Nigeria National Bureau of Statistics Brief: Sources of Income for Households in Nigeria LSMS-ISA, Integrated Surveys on Agriculture. www.nigerianstat.gov.ng

NEPAD (2002). NEPAD Short-term Action Plan: Infrastructure, UNCTAD and FAO, 2002.

Ocampo J. A. and Vos, R. (2008). "Policy Space and the changing paradigm in conducting macroeconomic policies in developing countries", BIS Paper 136, Initiative for Policy Dialogue at Columbia University, February.

Ochulor, C. L. (2011). Failure of leadership in Nigeria. American Journal of Social and Management Sciences, 2011, 2 (3): $265-271$.

OECD (2014). Promoting SMEs for Development. 2nd OECD Conference of Ministers Responsible for Small and Medium-Sized Enterprises (SMEs) promoting entrepreneurship and Innovative SMEs in a Global Economy: Towards a more Responsible and Inclusive Globalisation. Istanbul, Turkey 3-5 June 2004.

Okojie, C. E. E. (2013). Policy Space for Capital Control and Macroeconomic Stability: Lessons from Emerging Economies. Economic and Financial Review, Volume 51, Number 4, December 2013. CBN, EFR, Vol. 51. No.4 pdf.

Onyeiwu, S. and Liu, J. (2011). Determinants of Income Poverty in Rural Africa: Empirical Evidence from Kenya and Nigeria: Paper Presented at the African Economic Conference, Addis Ababa, October 26-28, 2011.

Oxaal, Z. (1997). Education and poverty: A Gender Analysis, Report prepared for the Gender Equality Unit, Swedish International Development Cooperation Agency (Sida), June 1997.

Oyelaran-Oyeyinka, B. (2007). FSS 2020 International Conference, SME: Issues, Challenges and Prospects, Financial System Strategy, 2020. Central Bank of Nigeria. http://www.cbn.gov.ng/fss/wed/SME_Issues, $\% 20$ Challenges $\% 20$ and $\% 20$ Prospects_Oyeyinka $\%$ 20Banji.pdf

Parker (2004). The Economics of Self-Employment and Entrepreneurship. Cambridge University Press.

Parker, S. C., Storey, D. J. and van Witteloostuijn, A. (2010). What happens to gazelles? The importance of dynamic management strategy. Small Business Economics 35, 203-226.

Porter, G. (2002). Living in a Walking World: Rural Mobility and Social Equity Issues in Sub-Saharan Africa, World Development, Vol. 30, No. 2, pp. 285-300, 2002.

Porter, G. (2014). "Transport Services and Their Impact on Poverty and Growth in Rural Sub-Saharan Africa: A Review of Recent Research and Future Research Needs", Transport Reviews, 34(1), 25-45. 
Premium Times (2017). How Buhari's social intervention programmes will work - Presidency January 4, 2016, Press Release http://www.premiumtimesng.com/news/top-news/196123-how-buharissocial-intervention-programmes-will-work-presidency.html

Reardon, T. (2001). 'Rural Non-farm Income in Developing Countries,' mimeo, Michigan State University.

SMEDAN (2007). Small and Medium Enterprises Development Agency of Nigeria, "National Policy on Micro, Small and Medium Enterprises", Federal Republic of Nigeria, SMEDAN, Abuja, Nigeria, January 2007, Annual Report, SMEDAN, Abuja.

Sonobe, T., Akoten, J. E. and Otsuka, K. (2009). The growth process of informal enterprises in Sub-Saharan Africa: a case study of a metalworking cluster in Nairobi. Small Business Economics, Volume 36, Issue 3, pp. 323-335.

UNICEF (2005). Education in Nigeria https://www.unicef.org/nigeria/children_1937.html

Wallace, J. (2000). Small Enterprise Development in Africa: Lessons from Success. Marshall University.

World Bank. (2005). World Development Report 2005: A better Investment Climate.

World Development Report (2008). Agriculture for Development. Washington, DC: The World Bank.

World Bank (2010). World Development Report: Development and Climate Change. Washington, DC: The World Bank.

World Bank (2011). Nigeria's Infrastructure: A Continental Perspective. Policy Research Working Papers. International Bank for Reconstruction and Development. https://elibrary.worldbank.org/doi/abs/10.1596/1813-9450-5686

World Bank (2013). World Bank Assisted Commercial Agriculture Development Project Disburse, Press Release, July 12, 2013. http://www.worldbank.org/en/news/press-release/2013/07/12/worldassisted-commercial-agriculture-development-project-disburse-over-n209-million-to-3000-farmersin-kano-state

World Bank Enterprise Surveys (2014). Nigerian Country Profile. http://www.enterprisesurveys.org/

World Bank (2017). Agro-Processing, Productivity Enhancement and Livelihood Improvement Support Project. The World Bank Group. http://projects.worldbank.org/P148616?lang=en 